\title{
Introduction: New Cosmopolitanisms: Rethinking Race, Geography, and Belonging
}

This collection of essays offers reflections on how cosmopolitical thinking can be, and perhaps needs to be, made "new" for our contemporary global ecumene. A key premise of the collection is the recognition that in the contemporary conjuncture, our understanding of cosmopolitanism should be open to new intersections with understandings of how "race" and ethnicity are being deployed. It should consider the connections between cosmopolitanism and cultural phenomena such as multiculturalism, diaspora, migration and varieties of neo-imperialism and (neo-)colonialism. Indeed, it is necessary to think of various cosmopolitanisms, rather than a singular cosmopolitanism. The political, particularly the nation form, interrupts, or poses a check to, cosmopolitan initiatives and aspirations, yet this book maintains that ethicopolitical concerns, complicating our understanding of cosmopolitanism, also amplify our understanding of what a reformed cosmopolitanism, or what I will elaborate below as cosmopolitics, might look like. In short it is a key contribution of this volume that it seeks to reorient our thinking about cosmopolitanism. It points the way to cosmopolitics (the de-construction and re-construction of cosmopolitanism), particularly by calling our attention to how such thinking in the contemporary globalized conjuncture must engage anew with race and ethnicity.

We live in an age in which we are witnessing ethnically driven civil strife within nation-states: the ongoing strife between Hindus and Muslims in Kashmir; the ethnonationalist Balkanization of the former Yugoslavia; the mutual genocide in Rwanda between the Hutus and the Tutsi; the Kurdish struggle for a homeland in Iraq that saw reprisal in the form of gas attacks targeting women and children; the ethnically motivated Arab Spring protests and the violence wreaked upon civilians in Tahrir Square; the ongoing civil war in Syria; but also-if on a different scale-the Black Lives Matter movement in the U.S. We are also witnessing, even more crucially, an era of more refugees than ever streaming across borders and living, more or less indefinitely, in nonpermanent camps or settlements worldwide. It is thus a newly urgent ethicopolitical imperative that contemporary cosmopolitanisms negotiate issues of race or ethnicity as they emerge as drivers of social change both within the nation-state and, simultaneously, transnationally.

This cosmopolitical project also requires anticipating and responding to interests that resist social change and to the resurgence of nationalism both in its benign democratic forms and in its virulent irruptions. Instances of the former type may be identified in the desire for a nation such as Israel to rebuild itself after political trauma or Haiti in the wake of a major earthquake, although of course these may be contested by rival nationalisms. Examples of the latter type, more worrisome, may be identified not only in reactionary ethnonationalisms produced through the Balkanization 
of the former Yugoslavia, but also in the re-emergence of America-first extreme right nationalists in the era of Donald Trump and Hungary's Prime Minister Viktor Mihály Orbán (no friend to cosmopolitanism), or in the rise of the ultranationalist Alternative für Deutschland (AfD) party in contemporary Germany, which secured a place in the national parliament for the first time, having won $12.6 \%$ of the vote in the 2017 election, alongside Angela Merkel's majority party. The AfD party's success, even if not a complete victory, was a mocking rebuke to Merkel's now-infamous neo-Thatcherite rallying cry that there was "no alternative" to her party's agenda. We cannot dismiss the re-emergence of the AfD and other resurgent ethnonationalisms as merely atavistic and insulated from the global. If anything, this party is remarkably cosmopolitan. Alice Weidel, one of the leaders of the AfD in the 2017 election, is a 38-yearold lesbian and former employee at Goldman Sachs who wrote a $\mathrm{PhD}$ thesis on the Chinese pension system, is fluent in Mandarin, and spent six years in China. The AfD party is hardly unique. Many ethnonationalist leaders are similarly exponents of ethnocentric right-wing politics and simultaneously thoroughly attuned to the workings of globalized economy and culture. Ethnonationalism and cosmopolitanism can be strange bedfellows. They are not necessarily strangers. As this volume emphasizes, forms of localism and rootedness can likewise be imbricated with cosmopolitanism; in any case they cannot be simplistically opposed. And it is precisely for such reasons that new perspectives on cosmopolitanism have become more urgent than ever. In both the public sphere and in academic analysis we need to re-imagine cosmopolitical responses to the new world order.

The contributors to this collection are certainly mindful of-and in many cases explicitly refer to-the long history of cosmopolitan thinking. This is after all a rich and deep genealogy, going back from a host of contemporary theorists amply discussed in the essays, to Immanuel Kant and the Stoic philosophers in the West. There is also the fact of transnational, cosmopolitan circulation of ideas, information, images, goods, people and capital along the Silk Road and across the Asian rim and throughout the non-Western world. One can get a sense of the range of contentious contemporary debates about cosmopolitanism from Joshua Cohen's edited collection For Love of Country: Debating the Limits of Patriotism, featuring Martha Nussbaum and many other well-regarded thinkers. ${ }^{1}$

1 See among others Joshua Cohen, ed., For Love of Country: Debating the Limits of Patriotism (Beacon P, 2002 [1996]); Tim Brennan, At Home in the World: Cosmopolitanism Now (Harvard UP, 1997); Pheng Cheah and Bruce Robbins, eds., Cosmopolitics: Thinking and Feeling Beyond the Nation (U of Minnesota P, 1998); Kimberly Hutchings and Roland Dannreuther, eds., Cosmopolitan Citizenship (St. Martin's P, 1999); Roel Meijer, ed., Cosmopolitanism, Identity, and Authenticity in the Middle East (Curzon, 1999); Vinay Dharwadker, ed., Cosmopolitan Geographies: New Locations in Literature and Culture (Routledge, 2000); Dilip P. Gaonkar, ed., Alternative Modernities (Duke UP, 2001); George Ritzer, The Globalization of Nothing 2 (Pine Forge, 2007); and Isabelle Stengers, Cosmopolitics I\&II (U of Minnesota P, 2010, 2011). 
Cosmopolitanist discourse has had such a diverse and diffuse history that it is expedient and even necessary to delimit the scope of this collection. Thus particular attention is given to categories of "race" and ethnicity in contemporary discourse on cosmopolitanism. "Racial" and ethnic divisions are almost defining features of discourse in the public sphere even (or especially) in multicultural polities. Contemporary globalization exacerbates differences among people. It emphasizes the importance of protecting borders as much as it promotes international or cross-border flows of labor, goods, services, information and capital. This contradiction is a critical object of academic study, especially in departments of political science, international studies, economics, women's studies, English and media studies, philosophy, sociology, anthropology, and more generally cultural studies. Many of the contributors to this volume are representative of this nexus of (cross-)disciplinary approaches, even as their particular focus is on race and ethnicity in contemporary national and transnational culture and cultural expression.

It is not only in large and sweeping gestures that the new cosmopolitanism is to be traced. It is also more immediately pertinent to local and "rooted" cultural phenomena and cultural production, at least to the extent that the local is valorized as the obverse of cosmopolitanism and a protection against kinds of cosmopolitanism that threaten the integrity of particular cultures or communities. This doubled perspective informs the essays gathered in this volume. They offer close, minute readings of cultural texts, whether they be poems, novels, artworks, or music, as records of particular cultures. Yet they also offer analyses that employ the lenses of intersectionality and other theoretical approaches such as feminist and postcolonial cultural studies to make larger points at the global scale. As collected here, the essays as an ensemble show that race and ethnicity cannot be understood in either local or cosmopolitan framings as if cordoned off from the categories of nation, class, age and socioeconomic position.

Crucial to this collection is a faith in and foregrounding of the minoritarianminor literatures, minority cultures, the wisdom of the marginalized. We can thus anticipate and accommodate the customary criticism that devoting intellectual energies to cosmopolitanism tends to underplay its toxic elitism, classism and racism, as though all cosmopolitanisms were indifferent or inimical to the concerns of the marginalized and the subaltern. Nor does this collection presume that only they can claim a cosmopolitan outlook who are able to travel across borders freely, voluntarily, and not under duress. This collection thus rejects the charge that cosmopolitanism is necessarily elitist. For that is no more than a facile prejudice against a research agenda: a premature and narrow refusal to engage seriously with cosmopolitanism. A renewed understanding of cosmopolitanism would ensure a cosmopolitical vision. Cosmopolitics can bring into sharper focus the ethicopolitical implications of contemporary global flows and particularly of the resulting contact among people of different races or ethnicities. 
A foregrounding of the minor also relativizes cosmopolitanism by introducing the perspective of scale. Several of the essays emphasize how cosmopolitanism is not expressed only at the macrocosmic level, as if only an internationalist constituency or as if only transnational traffic and translation were of interest. Rather, microcosmic expressions of cosmopolitan sensibilities may speak more satisfyingly of the potential to form cosmopolitical community even at the level of the local. Cosmopolitanism is not just for global elites. It also gives humane testimony to the everyday, even unremarkable, lived experience of people in the hinterlands, even in the most isolated of islands or in the most forgotten graveyards of a minoritized community in a poor city in the developing world. Smallness and ordinariness are not reducible to insignificance and banality. Nor can it be said facilely that "we" in the West or in the relatively developed global North enjoy the luxury of access to a cosmopolitan outlook "from above," while those who cannot afford to travel freely across borders are condemned forever only to be "local." For even in the Global South there are ways of imagining or making the world that might teach us how to live in greater harmony not only with our fellow human beings but also our planetary and indeed cosmic ecology. It may be that different groups construct reality itself in paradigmatically different ways. A paradigm shift might occasionally prove necessary. As the American "analytic” philosopher Donald Davidson puts this idea even more strongly-while suggesting some of the problems of "translatability" it poses-in the lexicon of analytic philosophy: "Reality itself is relative to a scheme: what counts as real in one system may not in another" (5). Indeed there is not yet a singular cosmos to which we all belong, although that may be a goal for a cosmopolitanism perfected, in a future that is not yet. Cosmopolitics highlights the ethicopolitical imperative to allow the reality experienced by minority groups not to be subsumed under a universalized, Westerncentered although nominally cosmopolitan, notion of what reality is.

Another related aspect of minoritarianism that emerges from the essays in this collection is the importance, especially to minorities, of the intimate, and of the domestic or private sphere, that is counterposed to the public sphere but also articulated with it. It is no accident that so many of the essays focus on novels, perhaps the medium most hospitable to the narration of intimacy. Politically speaking, intimacy may well be contingent in the political conditions given to and endured by many minoritized and marginalized people. Still, in the absence of adequate institutional infrastructure and state support, intimacy and the private domain constitute an important refuge from the presumptively irresistible power of globalized capitalism, from oppression and domination by repressive regimes, and from coercive force fields of civil strife within and across national borders. The "Syrian crisis" is a contemporary name for that from which intimacy and the private sphere offer a fragile shelter; but we could give it other names, including ISIS, South Africa during Apartheid, Sobibor ... The question is whether the worlding of intimate and microcosmic worlds can open a space for cosmopolitical justice. Arguably, the intimate worlds available to minority groups may be the most crucial space for cosmopolitical justice. For if justice, soli- 
darity and community mean anything, such meaning emerges only through shared feeling, common aspiration to true equity, a sympathetic connection that is larger than self-interest but one that returns to inter-esse (inter-being), without fetishizing "love" or other affective bonds. And it would be hard to think of any medium more suited to the expression of such intimacy than imaginative works, the focus of most of the essays in this collection.

What anchors the figure and category of minority in many imaginative works is the irreducible materiality of embodied human experience. But materiality is also "the Real," that which lies ultimately beyond the power of symbolization, as Jacques Lacan puts it in a psychoanalytic lexicon. This collection's emphasis on the minor is fundamentally a way to honor the principle that it is simply being human, in a radically material sense that lies beyond language and law, that guarantees the embodied human individual an inalienable right to dignity. Yet we must of course talk about, and honor, this inalienable right in language, as a matter of law. Importantly, for instance, it is enshrined in the very first clause of the Preamble of the Universal Declaration of Human Rights: "recognition of the inherent dignity and of the equal and inalienable rights of all members of the human family is the foundation of freedom, justice and peace in the world ... ." As the first Article of the document states, "[a]1l human beings are born free and equal in dignity and rights" (The United Nations). Was it not on the basis of this principle of dignity of the human being that Kant, perhaps the preeminent thinker of his time on the topic of "cosmopolitan right," insisted that the migrant who is fleeing mortal threat to her being deserves to be allowed to travel anywhere in the world, at least while the threat persists? In our own time, Jacques Derrida, addressing Kant, argued that there can be no limit to this call to hospitality; but by this very stricture hospitality is rendered "impossible." Yet it is precisely for this reason that the host is enjoined to honor the dignity of the guest-and joined at least etymologically to the guest (hospes: the term refers, "squintingly" or bidirectionally, to both the meaning "host" and the meaning "guest") as a human being, as Hannah Arendt also already observed before Derrida.

Hospitality's “impossibility" means that there ought to be no calculation-no temporal, interpersonal, emotional, or financial valuation-of how long or how far hospitality must extend. To submit hospitality to the calculus, and the limit, implied by value is precisely the problem to which Cesare Casarino points, invoking Spinoza as well as Marx:

What is destructive and self-destructive is to produce surplus and to experience being as valuable rather than as common, to produce and to experience one's own surplus, one's own share in being, precisely as one's to own-and hence as always liable to being captured, being dispossessed of itself, and being (dis)owned by others-rather than producing it and experiencing it instead as that which must not be disowned at any cost and indeed cannot be owned by anyone at all. (163) 
Human beings and their planetary co-existence (cosmopolitan communitas) cannot be reduced to the logic of value. As an alternative (following neo-Marxist thinkers including Jodi Dean as well as Antonio Negri and his collaborator Michael Hardt), Casarino proffers a communicative cosmopolitanism that is neither the traditional Gemeinschaft (the human connection among people in a true community) nor Gesellschaft ("society," as a more impersonal set of social relations and institutions)-that escapes the orbit of value:

there is no such a thing as a solitary thought, as an individual language, as a personal affect, or as private knowledge (even though we may experience all of the above as that which is most intimate and most unique about ourselves), and hence to express oneself intellectually, linguistically, affectively is to activate and mobilize exquisitely shared, collective, common capacities. (166)

This collection is inspired by the spirit of such a communicative cosmopolitanism as the form of potential solidarity cutting across national, racial, and ethnic and other borderlines, even though several essays focus on a single author's voice. Such a cosmopolitanism is in no sense complicit with either uncritical celebration of the cultural industries as necessarily emancipatory, or with Euro-Americo-centric, (neo-) Hegelian universalist utopianism. Culture-cultural production, the focus of most of the essays collected here-is communication. It carries the potential for more egalitarian worldings of our one world.

A new communicative cosmopolitanism could have a more critical force if it were to attend to certain key issues. "Who is the subject of citizenship? Is citizenship a necessary common frame to be shared universally? Is the cosmopolitan necessarily about the production of the sort of individual interest, will, and belief that most ideologies of citizenship appear to require?" (Pollock et al. 584). And how are we to theorize new political subjects of a nation-state that are hybrid, "extimate," that is to say both outside and inside the nation-state, simultaneously external and intimate? Such subjects complicate presumptively normative political subjectivity. They bring into sharp focus the gap between formal criteria for belonging and actual cultural barriers to acceptance of those who may be within the nation-state's territorial borders yet excluded in practice from meaningful membership in the state. There is also the parallel question of how to define the status of abjected subjectivities, for instance of "undesirable" immigrants who are targeted for deportation or "repatriation" or constructed as aliens who allegedly do not truly belong. As is evident today in Germany, France and elsewhere after the massive rise in the number of refugees, there are political consequences of defining someone as either an immigrant deserving of amnesty and citizenship, or on the other hand as guest worker, asylum seeker, refugee, potential threat or burden on the nation-state.

As emphasized above, an implicit value expressed in the diversity of textually and culturally specific readings collected within these pages is that it is not a totalized, universalizing, and singular cosmopolitanism that we ought to imagine, but cos- 
mopolitanisms, in the plural. Resisting the idea of cosmopolitanism conceived of as a totalizing, singular and universalist formation across time and geographical space, the essays in this book bring to light through their readings of cultural texts pluralized framings, sensitive to meaningfully different particular, local and minoritarian worldings of the world, rather than a single "universal" version of the social and political reality. Though of course not all the essays employ precisely these terms, such a sensitivity foregrounds the discussion of gendered, racial and ethnic vectors of minority identity. This premise can be elaborated through reference to what philosopher of science and sociologist Bruno Latour, building on the work of Isabelle Stengers, also conceptualizes as "pluriversality," which may for the current purposes be understood as a non-universalizable worlding of multiple, even incompatible, worlds or realities. This is part and parcel of the project of cosmopolitics (Latour, An Inquiry; We Have Never). Theorizing such pluriversality allows first of all a reframing of the contours and operational procedures that might reform and restructure multicultural co-existence at a time when it is imperiled, for example in the contemporary U.S. Witness the racist violence that produced the ethicopolitical response of the Black Lives Matter, Movement a bid to reform the carceral state and the racialized national culture. This movement constitutes an interrogation of the purportedly inclusive multicultural American society, while at the same time being a plea for inclusion.

Pluralism as a value holds in abeyance the coercive potentialities of any given universalism-including in particular "modernity," which tends to be propagated as a modular, teleological, Western modernity. Yet a genuine openness to the plural or pluriversal also destabilizes a false sense of confidence that "we" in the West are (always) already cosmopolitan in anything more than the most banal sense. Pluriversality ideally would resist a hierarchization of cultural world-views and practices (some more advanced pitted against the less developed and therefore inferior) while holding open the promise of transcultural solidarisms and cross-cultural exchange and learning.

Strictly speaking, pluriversality remains speculative, for we have to ask, "within what possible scheme or paradigm, necessarily transcendental or outside our reality and the others' realities, yet shared among all these realities, could we possibly recognize a reality that is not already real in our own reality?" (Davidson 9). Is there only one cosmos imagined differently by us and by other people? Or are there actually radically different worlds? Analytic philosophers such as Donald Davidson, Peter Strawson and their interlocutors have much to say about different worldings of the world. This too is a relativization of normative identity, of what we ordinarily regard unquestioningly as "our reality."2 Advisedly declining to privilege Western modernity

2 Donald Davidson's “On the Very Idea of a Conceptual Scheme” was the Presidential Address delivered before the Seventieth Annual Eastern Meeting of the American Philosophical Association in Atlanta, December 28, 1973. Davidson opposes, for example, the formulation of Peter Strawson with 
and universalism as a model or ideal for the Global South, many of the contributors to this volume instead analyze non-Western texts with care and modesty, mindful that they may not themselves be from the Global South, and sensitive to the arrogance of a neocolonial gaze directed at "the other." A cosmopolitical commitment to pluriversality requires vigilance against closure of the process of learning from others, or presuming that "we" are cosmopolitan and "they" are primitive, underdeveloped.

It is in this sense that a true cosmopolitics is always a proposal that is future oriented, "to come." As suggested above, cosmopolitics is distinguished in Stengers' work as in Latour's from the homogenizing and teleological tendencies of Kantian cosmopolitanism, which conceives of cosmopolitanism as a single, universal or common world (cosmos). Kantian cosmopolitanism posits a monolithic telos calling for all human beings to put aside their divisions and differences (call it chaos) and unite in universally shared humanity. Of course, Kant's racism and sexim fundamentally problematize his grand moral cosmopolitanism as well. The racism of his system of thought can be traced from well before the publication of the Critique of Pure Reason in 1788 at least until the important essay Toward Perpetual Peace in 1795, by which time he had curbed his racism. ${ }^{3}$ Thus, in "The Cosmopolitical Proposal," Stengers explicitly denies that cosmopolitics has "any relationship with Kant or with the ancient cosmopolitism” (994). Latour, extending Stengers' argument, insists that the cosmopolitical includes in its orbit not just the human but also the whole rest of "the cosmos"-the non-human as well as the human. The non-human too must enter any calculation of the cosmopolitical.

The rejection of an always-already universalized framing of the cosmopolitan, which is tantamount to a foreclosure of the cosmopolitical proposal, is a key strategy of Stengers' argument. She writes that:

[t]he prefix 'cosmo-' indicates the impossibility of appropriating or representing 'what is human in man' and should not be confused with what we call the universal. The universal is a question within the tradition that has invented it as a requirement and also as a way of disqualifying those who do not refer to it. The cosmos has nothing to do with this universal or with the universe as an object of science. But neither should the 'cosmo' of cosmopolitical be confused with a speculative definition of the cosmos, capable of establishing a 'cosmopolitics.' The prefix makes present, helps resonate, the unknown affecting our questions that our political tradition is at significant risk of disqualifying. (Cosmopolitics II 355)

that of Thomas Kuhn. For Strawson, there are different worlds. But for Kuhn there is one world imagined radically differently by different observers.

3 See Lucy Allais, “Kant's Racism,” Philosophical Papers Vol. 45, 1-2 (March and July 2016):1-36; and Pauline Kleingeld, "Kant's Second Thoughts on Race,” The Philosophical Quarterly, Vol. 57, 229 (Oct. 2007): 574-592. His sexism is on clear view especially in Immanuel Kant, Anthropology from a Pragmatic Point of View, Trans. and Ed. Robert B. Louden (Cambridge: Cambridge UP, 2006). 
Here cosmopolitics is the process of unfolding the political, conceptualized as the potential ways in which pluriversal worlds and identities may be unfolded into a conversation that might function as a commons. Stengers thus stresses the reciprocal relation of cosmos and politics. As Latour elaborates the reciprocity, "cosmos in cosmopolitics resists the tendency of politics to mean the give-and-take in an exclusive human club. The presence of politics in cosmopolitics resists the tendency of cosmos to mean a finite list of entities that must be taken into account." The important thing is that "[c]osmos protects against the premature closure of politics, and politics against the premature closure of cosmos" ("Whose Cosmos" 454).

\section{Section I: Rootedness and the New Cosmopolitanism: Sovereignty, Hosts, Guests and Hospitality}

Essays in the first section of this collection touch upon several key problematics associated with cosmopolitanism. Not the least of these is the classic opposition, articulated for instance in the work of Étienne Balibar, of national sovereignty and Immanuel Kant's cosmopolitan right "of a stranger not to be treated in a hostile manner by another upon his arrival on [foreign] territory"-a right to visit (droit de séjour) though not to settle permanently (Kant, Toward 82). In an era that has witnessed massive transnational migration and seemingly endless refugee crisis, what should cosmopolitan right mean, and how do we resolve its conflict with the imperatives of sovereignty? ${ }^{4}$ How to reconcile a newly imagined cosmopolitical ideal for all persons regardless of race, creed and color (as the saying goes) with the demands of particularity? What should a nation-state's policy be for trans-border migrants in extremis or for economic migrants and the very different sans papiers (those who do not have travel or identification documents), some educated, some not, some young and fit

4 For Kant cosmopolitan right is the right of all human beings to the territory of the entire globe, simply by virtue of having been born on the earth. Yet this would seem to license "primitive accumulation"-one cannot claim land already possessed by someone else, or by extension the territory held by a sovereign state, except through agreements and contracts. In two key essays, "Perpetual Peace” and “The Metaphysics of Morals," Kant conceptualizes this importantly as an equal right to land, by virtue of taking possession of land. We are all, irreducibly, citizens of the world. Yet even when land is held by someone else, any human being ought to be allowed to travel into or through it, given what Kant terms "determinate limits." These limits are in tension therefore with a universal "right of hospitality," the right of any foreigner whose life is threatened to be received hospitably in any given nationstate. By the same token, however, the sovereign state has an equal right to ask the stranger to exit the territory as long as there is no longer a threat to her life. In this account, the stranger is not exactly a guest but a visitor, although Derrida insists that there is no limit to hospitality in this context, which makes it "impossible." Cosmopolitan right also extends to the right to unfettered trade, travel or other transactions, including exchanges of communications and flows of capital, information, images etc. (Kant, "Perpetual Peace” 120; “The Metaphysics” 137). 
and others not, who voluntarily come to relatively prosperous countries seeking to improve their own prospects without falling under the protection of any emergency clauses of hospitality? And what does sovereignty mean today, when borders and passports function in ways unanticipated at the time of the Treaty of Westphalia or indeed at the time of the institution of Western nation-states in the wake of the French Revolution, which, as John Torpey suggests, was the key turn in the annals of nationstate formation in the Western context (to say nothing of the temporalities of the non-Western world) (2)? At the heart of these questions is a family of contradictions between rootedness and cosmopolitanism.

New cosmopolitanisms attempt to address these contradictions by positing, in the paradoxical formulation offered by Anthony Appiah, variations of rooted cosmopolitanism. A rooted cosmopolitanism articulates a sense of being a citizen of the world with an appreciation of the richness of shared culture, the "world of cultural and social variety as a precondition for the self-creation that is at the heart of a meaningful human life” (268). But even Appiah's suggestive compromise coded as a paradox does not directly take on the question of the difference that racial or ethnic, let alone gender and class, distinctions make. Paul Gilroy is if anything more preoccupied with race and racism in his critique of cosmopolitanism against the backdrop of "postimperial melancholia” (99) - he rejects a racialist, triumphalist, "imperialistic particularism" that cloaks itself in "universal garb" (4). Concepts such as multiculturalism and globalization elide the "bloodstained workings of racism" (4). What is better is a planetary consciousness, "rooted" and local yet without giving up on the cosmopolitical (79).

Taoufik Djebali’s chapter, “Africans in Calais: Migrants, Rights, and French Cosmopolitanism," frames the question of cosmopolitanism by rooting it within a French context. He presents a particular, situated sociological examination of the presence of migrants in the port city of Calais. He raises issues that are central to this collection's inquiry. These include the social crisis precipitated in France (as in Germany) by the influx of migrants and also the conflict between "racial" and ethnic groups, the meaning of French identity and the scope of French inclusiveness particularly from the perspective of immigration law. As Djebali points out, to consider cosmopolitanism in this small-scale political context highlights not only the socioeconomic, political and legal questions of the local inhabitants, but also requires us to return to the abstract moral and philosophical underpinnings and rationales of cosmopolitical thinking, dating at least from the Kantian conception if not from before the Enlightenment. Though he maintains that "[n]o other country in Europe embodies the dilemma of cosmopolitanism" quite so starkly, Djebali highlights the value of such a contextualized rethinking of a specific migrant community not only within the immediate contested contexts of French society but within the global community. Such rethinking interrupts or interrogates received notions of cosmopolitanism and points up the need to imagine "new cosmopolitanisms." 
Anna Pochmara's chapter, “ 'In the Tangled Lily-bed': Rhizomatic Textuality and Rooted Cosmopolitanism in Pauline Hopkins's Of One Blood” assesses the novel's narrativization of a similarly rooted cosmopolitanism that manages to resist a reactionary "nationalism of the oppressed." The latter is untenable anyway because it is merely a "reinscription of ethnic authenticity and racial essentialism." Hopkins' text, in Pochmara's account, transcends the regressive recuperation of a putatively "authentic" past or "pure" origin. It articulates instead a rhizomatic textuality or "minor literature," in the terms proposed by Deleuze and Guattari in their discussion of Franz Kafka's iconically minoritarian fiction. As Pochmara notes, Deleuze and Guattari share the concerns and commitments of postcolonial and cultural studies theorists, particularly their anti-racist agendas. Against the nostalgic "roots" fantasy, Pochmara suggests, and beyond the relatively myopic and essentialist Africanist narratives of Martin Delaney or Marcus Garvey, Hopkins offers a "rhizomatic," heterogeneous and even "aporetically" ambivalent vision, a hybrid and future-oriented cosmopolitanism.

Marta Werbanowska, in her chapter entitled "Envoy to the World: Nomadic Cosmopolitanism in Yusef Komunyakaa's The Emperor of Water Clocks," also tracks a rooted cosmopolitanism, this time in Komunyakaa's poetry. The poet draws his reader's attention to asymmetrical global cultural flows and circuits of power, culture, and historical memory to ask whether a new cosmopolitical imagination might form the matrix of community simultaneously transnational and rooted, aesthetically nomadic (anticapitalist, non-individualist, non-universal) and relational. In the imagined cosmopolitical community, the planetary can be reimagined as a commons, the shared concern for all human society. The capacious vision Werbanowska identifies in Komunyakaa aligns with Stengers' concept of cosmopolitics referenced above as counterposed to a totalizing Kantian embrace of Eurocentric universalism. Introducing difference within the space of the admittedly utopian world community, Komunyakaa invites a variety of global voices towards a cosmopolitics in some future, "to come."

Against the canard that cosmopolitanism necessarily indexes elite privilege, Carol Breckenridge et al. suggest that "cosmopolitans today are often victims of modernity, failed by capitalism's upward mobility, and bereft of those comforts and customs of national belonging” (6). Aparajita Nanda's chapter takes this inversion as the starting point for her meditation on Kiran Desai's novel, The Inheritance of Loss. Migrants of all kinds, including both exiles wrenched from their homelands and well-heeled diasporics who make their homes and their workplaces wherever they reckon lies their greatest advantage, must be considered in the analytic of a new cosmopolitanism, especially one sensitive to class and gender as well as to race and ethnicity. Of course we have to be careful to resist and undermine an elitist perspective. Nanda attempts to heed this caution. She draws on Homi Bhabha's concept of minoritarian or vernacular cosmopolitanism to thematize the experiences of underprivileged migrants, pointing to a "hybrid pastiche of discrepant narratives." In discussing Desai's novel, she highlights protagonist Harish-Harry's painful hybridity (even this character's 
name is hybrid), experienced as failed cosmopolitanism-and, worse, his thwarted or grotesquely distorted bourgeois aspiration to assimilation and social advantage. As an immigrant in neo-colonialist or capitalist culture, Harish-Harry even stoops low enough to exploit fellow immigrants. This behavior may not be a characteristic pathology of the outsider, immigrant or misfit. However, in the novel it emerges as symptomatic of the hybrid experience of unsettled immigrants or diasporics. Desai emphasizes this by contrasting Harish-Harry with Saeed Saeed, starkly highlighting the power of contrasting "rooted" and deracinated cosmopolitanisms. She also foregrounds the powerful distortions introduced by race and ethnicity in postcolonial contexts.

\section{Section II: Minority Bodies}

Precisely because a true cosmopolitics is always "to come," it emerges, as it were latently, within the realm of imagination or invention-what in classical rhetoric was called inventio. It is for this reason that several essays gathered here turn to works of imagination, cultural and especially literary works. Most of these are historically situated readings. Some of the other essays in this collection focus on historically and sociologically oriented case studies and are thus useful in providing (necessarily plural, often racially charged) contexts for a study of cosmopolitanism. The essays implicitly or explicitly propose rationales for revisiting received notions of cosmopolitanism. They suggest that context and background are crucial. They also show that a "new cosmopolitanism" cannot afford to neglect the everyday, material reality, particularly as it pertains to race and ethnicity. This is how cosmopolitanism might be recast as cosmopolitical: by taking seriously and critically attending to the constraints of material and embodied particularity, especially in the case of raced bodies. Such a cosmopolitical project aligns with Gilroy's point about theories of cosmopolitanism revealing a blind spot regarding the issue of race. Creative works of the imagination, especially, ground us in particular embodied experience. When such works prove capable of new worldings of the world, they bring to the fore individual subjectivities that "differ" from one another irreducibly. These subjectivities are situated in specific contexts, particularly those that introduce difference, indeed what deconstructive literary theory has elaborated as différance-interminable deferral of meaning, irreducible cultural difference, temporal lag or spatial displacement. These works of the creative imagination are adduced often as interruptions of grand narratives in favor of petits récits (microcosmic worldings through minor narratives). They introduce asymmetry and destabilize moral, ethical, and value codings; they interpolate diverse demurrals from dominant discourses of cosmopolitanism; they dramatize deferrals of narrative closure and make imaginable resistance to totalization. Precisely because they dissent from the universalism of some conceptions of cosmopolitanism, minority 
bodies ("raced," gendered, ethnic, handicapped, or otherwise marginalized bodies) are thus the linchpin of the "new cosmopolitanism."

Yet it must be said that there has been a reluctance outside of literary and cultural theory to foreground the cosmopolitical dimension of minority writing even when its international provenance or transnational themes are prominent. Susan Koshy writes that "despite the embrace of cosmopolitan themes and forms by many writers, including [Jessica] Hagedorn, scholars in the field have been slow to engage the cosmopolitan visions of minority writers." What is more, the "ambivalence toward cosmopolitan analytics in ethnic studies is paralleled by the marginalization of race, ethnicity, and non-Western cultures in discussions of cosmopolitanism" (593-594). This is in one sense understandable. Resistance to cosmopolitanism is often construed as an ethicopolitical stance against Eurocentric universalism, and voiced through formulations of "localism" and "glocalism." Besides, it is also important to acknowledge a need to interrogate universalism along a temporal axis. Some subjects, Inderpal Grewal reminds us, participate in cosmopolitanism "intermittently or in unstable ways" (38). Yet it is precisely such considerations that make compelling a focus on the creative imagination. The asymmetries and asynchronicities of participation in the cosmopolitical imagination are most compellingly voiced in cultural products such as theater, music, visual and performance art, film and especially literary works emerging from minority writers. Along with race and ethnicity, another critical dimension of the new cosmopolitanisms is that they retain an at least implicit gender signature, and through such intersectionality highlight subversions of majoritarian representations of national culture and even queerings of gender norms within the narratives of nation. Thus, in the representation of minority bodies the concerns that animate a cosmopolitical project become powerfully resonant because they illustrate what it means to pluralize the world, to emphasize différance and thus reform normative ideas of identity and social life.

Taking as his illustrative example Arundhati Roy's novel, The Ministry of Utmost Happiness (2017), Samir Dayal argues in favor of a normative materialist cosmopolitanism: a critical reframing that is necessary for any cosmopolitical project. This regenerated cosmopolitanism, as Dayal elaborates, reconfigures received notions of cosmopolitanism. Dayal foregrounds Isabel Stengers' cosmopolitical project committed to cosmopolitical (and not just cosmopolitan) justice-but he refracts it to emphasize the importance of attending to the materiality of minority subjects, persons of the world's precariat. Stengers' vision of cosmopolitical justice is truly cosmic, and does not privilege just human beings-this is a cosmo-politics that does not limit itself to human society, excluding the rest of nature or the universe. That exclusion has defined Western modernity at least since the time of the Enlightenment. Nonetheless, Dayal's exploration of the cosmopolitical project is strategically constrained within the parameters of human society, without either sequestering human beings from nature or privileging them. Furthermore, the scope of Dayal's cosmopolitical vision is also tactically delimited to foreground the minoritarian, indeed the microcosmic, 
against the dominant or majoritarian, which tends to be totalizing and universalising-macrocosmic. And if microcosmic cosmopolitics is particularly concerned with the minoritarian that also means that it is focused on the experience of the everyday for the marginalized. This everyday life finds its exemplary medium in the novel genre, and certainly in Roy's novel about subjects who are perhaps among the most abject within Indian society. But a theoretical argument for the normative-for how things ought to be if cosmopolitical justice is to be realized-is necessary to supplement Roy's fictional exploration. Thus Dayal develops his delimited argument for a normative materialist cosmopolitical project through a close reading of Roy's novel, which imagines a single world, to which everyone (including animals to the extent that they are part of the larger orbit of human society), can belong, regardless of gender, race, sex, national origin or socioeconomic status, and in belonging enjoy a presumption and guarantee of finding justice reigning universally. Dayal suggests that Roy's representation of Anjum's brown and transgendered body is intended to recuperate the dematerialized body of the marginal and subaltern subject, who tends to "disappear" within the macroscopic narratives of nation. And although the utopia of cosmopolitical justice may seem to recede perpetually to the point of vanishing, it remains aspirational, a future "to come." Justice is not just a disembodied, abstract ideal. Its fullest realization must crystallize in the material, embodied experience of the minority body, in the everyday life of the marginalized.

The minority body is also a key focus of Raphaël Lambert's chapter, "From Édouard Glissant's 'The Open Boat' to the Age of Mass Migration.” Lambert highlights the linkages between the Black Atlantic's massive slave traffic and contemporary racial and ethnic divisions. The slaves' descendants live lives that continue to be marked by that traumatic "Middle Passage.” Lambert foregrounds Glissant's cosmopolitical categories of "relation" and creolization. The former is a poetics of identity modulated through interpersonal exchange that is perennially fluid and rhizomatic. The latter signals the hybridizing and spatializing effect of such relationality-cultural mixture-as well as the decentering movement that resists the reification and atomization promulgated in liberal political theory. Yet creolization also operates to counter the homogenizations perpetrated on both minority cultures and minority subjects (particularly those of the Global South). Lambert's interest is not just in the travels and travails of transnational migrants. He also highlights possibilities for constructing new, even mongrelized, identities inhabiting newly configured minority positionalities. Advisedly cautious about positing hasty equivalences between the Middle Passage and contemporary lines of migrant flight, Lambert discusses both the migrants' "errantry" across borders and their "tracing” of lineages back to the original "brutal" but also productive dislocation, from the mother continent of Africa. It is then another variation on the theme of rooted cosmopolitanism, this time complicating both a simple attachment to roots and a glib, deracinated cosmopolitanism. Glissant's negotiation through such a complication provides a ground-not mere territory-from or upon which the migrant or refugee body can tender a claim to cosmopolitical right. 
As part of her project on eugenic thinking, Ewa Luczak focuses in her chapter on interrogating the obstacles to friendship across racial lines by considering Infants of the Spring, Wallace Thurman's novel. The novel explores the vectors of interracial and trans-Atlantic friendship, set in the early decades of the 20th century, in a time when eugenic discourse was in the ascendant. Luczak's chapter is a contextualizing contribution, reframing a new cosmopolitanism in terms of the racializing of non-normative bodies. It explores the racial obstacles to cosmopolitan friendship, and suggests the utopian possibility of achieving that friendship precisely through acknowledging race and ethnic divisions as political reality. Luczak invokes an Arendtian category of cosmopolitan friendship. She asks how political and racial divisions, as well as "the discourse of racial absolutism," all of which seem to have an increased saliency in the contemporary moment, "affect the shape of inter-racial and cosmopolitan friendships." For Arendt there are two "shapes" of cosmopolitanism: one constituted by a shared suffering among "the repressed and persecuted, the exploited and humiliated," a communion of pain if you like, which may promote companionable coexistence within a polity but which also excludes the group from meaningful membership in a cosmopolis. Here friendship pays the price of social invisibility. True cosmopolitan life on the contrary enables a worlding of the world through friendship. This second variety of cosmopolitanism is the ethical and cosmopolitical project, a goal for a reimagined cosmopolitanism, Luczak maintains, drawing simultaneously on the models of Jürgen Habermas and David Held's neo-Kantian reconfigurations of cosmopolitanism, and on Rosi Braidotti's pan-humanist "nomadic becoming-world." The goal of articulating the abstract principles of neo-Kantian cosmopolitanism chez Habermas and Held, and in Braidotti's cosmopolitanism "from below," is to take seriously the abstract principles underpinning a new cosmopolitanism: nurturing a planetary human society and attending to the material reality of ordinary people divided by race as well as ideology.

Joanna Ziarkowska's chapter on Leslie Marmon Silko's novel Gardens in the Dunes considers whether the minoritarian-in this novel, embodied in Indigo, a Native American protagonist-can be subsumed into the category of the cosmopolitan, in other words, whether she can be positioned as an "Indigenous cosmopolitan.” This is a term taken from the title of an edited collection by Maximilian Forte published in 2010. Ziarkowska is careful not to merely refract, and thereby diminish, Native American subjectivity and textuality into a presumptively cosmopolitan but effectively EuroAmerican world-view. Rather, drawing on Cheah's formulation that "cosmopolitanism and human rights are the two primary ways of figuring the global as the human," and invoking a range of recent studies of cosmopolitanism in the field of literature, Ziarkowska foregrounds Native approaches to Native American literature, and indeed to everyday Native life, that dissent from dominant EuroAmerican critical framings. Thus her chapter's broader aim is to describe a project of indigenizing cosmopolitanism itself in the study of Native American texts by foregrounding key categories such as nation, separatism, and relation. She points up fragmented 
sovereignties, including Native sovereignties, that nevertheless might lay claim to cosmopolitanism, or even aspire to a cosmopolitics.

\section{Section III: Minoritarian Mobilities}

Essays in this volume foreground categories of race and ethnicity, not just in the national-state frame but also as crucial to understanding new mobilities. Diaspora cultures and transnational migration, especially in the case of refugees or forced exiles, constitute a condition of perpetual migrancy that at least at first glance appears to be the contrapositive of cosmopolitanism. But the concept of migrancy is also enriched and complicated by the notion of mobility (Tölölyan; Vertovec and Cohen). There is a crucial contrast between a cosmopolitan imagination in which goods, services, information, images, capital, and especially bodies, flow or circulate in an often rigidly controlled and sometimes frenetic pace across transnational borders-and the severe constraints placed on the ability of especially people from poorer nations in the Global South to do the same. Yet an equally critical distinction ought to be drawn between the articulations of cosmopolitanism at the level of the public sphere and in the intimate sphere. This is after all why contributors to this volume, adopting a bifocal perspective, emphasize rooted cosmopolitanisms.

To emphasize "mobilities" as part of the project of this collection is to highlight the intersection of cosmopolitanism with minoritarian subjectivities. Among the contributors who focus on minoritarian transnational migration is Maria Frias. She emphasizes that between the 1950s and the 1960s Spain was a major "sender" of unskilled migrant workers. Today, Spain has become a "receiver" of migrants from the African continent-in particular from the sub-Saharan countries. Starting in the late 1980s, mostly young, strong men were the first to arrive. Yet Frias' focus is not on these but on a much more vulnerable demographic-“African women's bodies in transit from West Africa to Spain.” She explores these subjects through a discussion of Gerardo Olivares's film, 14 Kilometros (2007), highlighting an analogy between the Slave Trade and "contemporary human trafficking and migrating subjects," underscoring that a new cosmopolitan is needed to attend to those whose mobility is not that of elite citizens of the world but of a critical precariat. Migrants are often marooned in the limbo of being "guests" of receiving nations such as Spain. Cosmopolitical justice must not ignore their difficult case, irrespective of national origins, class, or race/ ethnicity. And yet the obligation of cosmopolitical hospitality on the host nations has a particular piquancy when race and gender are factored in intersectionally into the ethicopolitical demand of cosmopolitan right.

In her chapter entitled "Afro-Asian Critical Cosmopolitanisms in William Demby's 1950s Reportage from Postwar Japan,” Melanie Masterton Sherazi offers a nuanced close reading of From a Japanese Notebook, unpublished reportage by Demby. Demby's spatial displacement-his “alienation”-as an African American 
observer in Japan is in both senses critical. The author's perspective as a minority Western subject observing an Eastern culture in which he inscribes himself is shot through with this multidimensional alienation. His book is "distinct from, even if not entirely outside of, Orientalist ethnographies and Western travel writing about Japan" and more generally pitched against Enlightenment constructions of the other. Furthermore, through its "subtle emphasis on ways of (mis)reading the world, the book refuses claims to mastery, dwelling instead in moments of indeterminacy" but also on passages to shared humanity. This is a form of cosmopolitan mobility and distance (ironizing the clichés of cosmopolitan sympathy) premised on Demby's own outsiderness vis a vis Japan. It is simultaneously a repudiation of his own racist indoctrination about Japan as a World War II enemy of the United States. This is no stereotypical affirmation of Japan's inscrutability to Western eyes. Sherazi stresses that Demby "captures glimpses or 'snapshots' in Japan of what Bhabha has termed 'spectral sovereignty,' whereby the nation-state inheres, even in a 'tattered' form," and via a negative ontology that resists essentialisms imposed from without. Yet even this negative ontology traces a cosmopolitanism rooted in relationality as a spatializing vector. In a further twist, it is also a cosmopolitanism anchored in Demby's very personal and indeed idiosyncratic viewpoint, complicated further by the autobiographical inflection of his writings.

The new cosmopolitanism's affirmation of pluriversal expansiveness and inclusiveness produces its own contradictions or challenges. In different ways and to different degrees, essays in this volume help us to see some of these contradictions or challenges. Some essays highlight the risk of deracination (perpetual homelessness, forced mobility in a restless search for human attachment). Others focalize the problematic positionality of minority bodies within the nation-state or the fragmentation or even occlusion of the minority body as such. Still others underscore the profusion of (shallow) belongings if not spectral sovereignties. Hanna Wallinger's chapter on Taiye Selasi's Ghana Must Go takes as an impetus Ketu Katrak's caveat in "Colonialism, Imperialism, and Imagined Homes," that postcolonial exiles and other migrants may experience a surfeit of "roots" and "locations." The implication is that there is no anchoring, no fixed material embodiment available to them. This can become a profound source of dysphoria. The minority bodies in question are perennially and ubiquitously out of time and out of place. For some minority bodies, cosmopolitanism is experienced negatively, as a double dislocation that renders diasporic subjects into a kind of limbo in which they feel they are within a social context such as a nationstate but never truly accepted as members of the community: "neither just this nor just that" (Dayal). Selasi simultaneously foregrounds rootedness and an ambivalent, problematic cosmopolitanism: the sense of being both inside and outside cultures, not always by choice, at the "intersections of histories and memories." The author "positions herself as an Afropolitan"-a multilocal African of the world, perhaps even "lost in transnation," as she herself phrases it, with some autobiographical wryness. Is this not analogous to the condition diagnosed by Arendt as irretrievable loss? 
Selasi's novel presents an account of multiplex displacement, including a dislocation back to, and from, a putative "homeland" where the cosmopolitan or diasporic experiences a double alienation, including her alienation from any ethnic belonging. Yet a complacent rootedness would hardly be a better alternative than the proliferation of quasi-belongings and unceasing displacements, none permanent, shuttling across geographies and identities in "transnation."

Focusing on a very different African context, Kudzayi Ngara considers Ivan Vladislavić's The Exploded View as a multi-perspectival narration of imbricated spaces to highlight those spaces as not just dead locality but as characterized by irreducible mobility: the "transient social and material spaces of the city in which characters are located and imagined events take place." This consideration focalizes the "construction and spatialization of urban identities in the context of the South African transition to the post-apartheid state.” Ngara highlights the traffic among the many people who traverse postcolonial city-space in a truly "new cosmopolitan" condition. What is most important is that the entanglements among those new cosmopolitans remain irreducible to bounded or fixed national identities. Yet, by the same token, the orbit of these entanglements permits only "truncated cosmopolitanisms.” A key contribution of Ngara's chapter is its de-essentialization of identity and its inter-imbrication of the culturally rooted and the cosmopolitan. This is best illustrated in Ngara's portrayal of the character Majara's attempt to claim an “Afropolitan” sensibility in his art practice, precisely as an anticipation of the possible charge of cosmopolitan alienation or outsiderness, and against the possible objection that his "cosmopolitanism" is really an appropriation and commoditization of the culturally "local."

\section{Section IV: Spaces and Vectors: Migration, Hybridity, Creolization}

Migration if not mobility has long been a staple category describing the impact of modernity on contemporary life. It is impossible to deny that in the contemporary conjuncture migrancy has become an irreducible and almost irresistible vector of globalization. No major culture today is immune from the effects of transnational migration. This surely is another reason why new perspectives on cosmopolitanisms are more urgent today than ever. The linkages among geographical or geopolitical spaces, as well as global flows of capital, labor, information, images, and goods, feature prominently in policy deliberations and theoretical debates. They also figure importantly in creative works exploring life under conditions of contemporary globalization. Andrea O'Reilly Herrera's chapter challenges traditional definitions of the cosmopolitan that tend to neglect the dimension of spatiality, and instead underwrite a paradoxical belonging. This empty cosmopolitanism leaves the citizen-subject suspended simultaneously in an everywhere and in a nowhere ("cultural or ethnic weightlessness"). O’Reilly Herrera's chapter explores a "post-1959 Cuban political discourse on both sides of the Florida Straits [that] has tended to be nationalistic and territorial and to 
make nativist claims to authentic cultural or national identity." Her discussion is an example of a new cosmopolitan approach that would displace Cuba as a "unified category of analysis," to float the island as it were. This is a reperspectivization and "repetition" of Antonio Benitez-Rojo's influential conceptualization of a Caribbean island of paradoxes that are always self-deconstructing, repetitions in an ongoing cosmopolitical project forming and reforming itself in unpredictable and unstable massings. As a cultural node in global flows, Cuba has long been "eclectic and cosmopolitan" rather than being tied to any essential Cuban core. O'Reilly Herrera illustrates through a consideration of Cuban artist Leandro Soto's curatorial project CAFÉ: The Journeys of Cuban Artists, "a radically inclusive, itinerant, and evolving art exhibition." Building on Ella Shohat's notion of the nation as a relational category, she develops the idea of Cuba and Cuban cultural expression "within a kaleidoscopic framework ... as a series of communities (located both inside and outside the island), which are in relation to perspective conceptualized as both migratory and rooted."

Particularity and universalizing cosmopolitanism are too often opposed in theoretical debates. Each category on the (logical but also political) "left" of the equation is pitted against the category on the "right." A new, critical cosmopolitics could interrogate this oversimplification, highlighting the ambivalent articulations of the personal and the public, the local and the global. Situating itself within a burgeoning sub-speciality of Cultural Studies-“mixed race studies"-Malin Pereira's chapter offers an analysis of the poetry of former U.S. Poet Laureate Natasha Trethewey, biracial daughter of an African American Southern US mother and a white rural Canadian father. She reads Trethewey's Beyond Katrina alongside the "cosmopolitan, ekphrastic" poems in the collection Thrall as a pair, to underscore how Trethewey "shifts in Thrall to an international array of visual materials and employs what could be argued is a cosmopolitan mode, ekphrasis, to comment upon them." A main focus for Pereira is Trethewey's “angry cosmopolitanism." The anger is reflected, in Beyond Katrina, in "meditative scenes of recognition and insight performing an ongoing critique of structural inequities in the U.S.” Still, Pereira suggests that Trethewey's anger in Thrall "is not mulatto rage at or confusion about her mixed race identity." It is in a critical sense an anger at a geospatial opposition between what mainstream, majoritarian white America means in the United States national imagination and minoritarian spaces metonymically represented by Mississippi's Gulf Coast, standing in for the Black South generally, analogous to the Global South. The anger Trethewey names is a "slow-to-constitute itself anger" at the unequal treatment of blacks. Borrowing Rob Nixon's phrase, Pereira identifies this as "the slow violence" 5 and other multifarious

5 In Slow Violence and the Environmentalism of the Poor Nixon writes: "By slow violence, I mean a violence that occurs gradually and out of sight, a violence of delayed destruction that is dispersed across time and space, an attritional violence that is typically not viewed as violence at all. Violence is customarily conceived as an event of action that is immediate in time, explosive and spectacular 
harms, indignities and discrimination visited on them. It is an anger that also finds a much more personal resonance in this book of poems. Trethewey's anger is directed against her own white father, who neglected and became estranged from his daughter but to whom Trethewey's book is also dedicated. He becomes a figure for the "parent" nation's racist neglect and abandonment of its black family members.

With intersectional acumen, Trethewey frequently references the history of colonialism as it is articulated with the economy of sexual exploitation and the geopolitical trauma of the displacement of black people through the arc of slavery. In one poem in Thrall Trethewey tinctures the lingering pain of traumatized blackness with wry but colloquial humor: "How like a dirty joke / it seems: what do you call / that space between / the dark geographies of sex? / Call it the taint-as in / T'aint one and t'aint the other- / illicit and yet naming still / what is between. Between / her parents, the child, / mulatto-returning backwards ..." (25). This hints at another major subtext of the essays in this collection-the mobility of even local, rooted, particular bodies is counterposed to the qualitatively different but defining mobility of the "cosmopolitan." It also suggests why a new cosmopolitanism sensitive to race and ethnicity must be bifocal, relational.

Relationality emerges frequently as a key theme in the chapters that make up the present collection. Trethewey laminates in her poetry the politics of the national family and her own family. For Joanna Jasińska, in her chapter for this collection, it is again the family that figures as the fundamental social unit and fulcrum for cosmopolitan life. Jasińska cites Ulrich Beck's imperative of constructing a global or cosmopolitan family as a possible hedge against the corrosive impact of modernization. In his book, Risk Society: Towards a New Modernity, Beck describes that impact as involving, among many other transformations, "changes in lifestyle and forms of love, change in the structures of power and influence, in the forms of political repression and participation ..." (50). In other words, public as well as intimate life are put under enormous pressure by forces of modernity. Could a "world" or "cosmopolitan" family, presenting itself as a model of a transcultural and transnational relationality, be a bulwark against modernity's depredations? Jasińska explores this question not through theoretical arguments (despite her framing discussion of Beck) or works of creative imagination, but through a study of educated and long-married Polish-American couples she conducted between 2012 and 2015, towards her doctoral dissertation.

in space, and as erupting into instant sensational visibility. We need, I believe, to engage a different kind of violence, a violence that is neither spectacular nor instantaneous, but rather incremental and accretive, its calamitous repercussions playing out across a range of temporal scales" (2). In Beyond Katrina, Trethewey unveils the slow violence of environmental predation of her former home, detailing the post-Hurricane Katrina devastation and inequitable rebuilding of the Mississippi Gulf Coast and its impact on her family. 
Anna Sosnowska's attention is also on relationality in connection with Polish diasporics-but unlike Jasińska she studies only the diaspora in the United States. She identifies and discusses two types of cultural cosmopolitanism among the Polish Greenpoint immigrant community leaders in the city-space of New York. The first is the "new" and relatively elite, metropolitan, cosmopolitanism of educated boomergeneration Polish community leaders, who thrive on the city's ethno-racial diversity. The second is the quotidian economic, even opportunistic, cosmopolitanism afforded by the working conditions, (with all their racial, ethnic, class and gender dynamics factored in) of immigrant or diasporic laborers and usually small-scale entrepreneurs and others who work in the parallel economy. These laborers and small entrepreneurs tend to live in ethnic enclaves in one of what Saskia Sassen classifies as global cities. While her focus is on a particular ethnic demographic, and contextualized within the exceptional metropolitan space of New York City, Sosnowska's point is that these two types of cosmopolitanism can be identified as a shared pattern for over a century among many immigrants, and therefore of interest to students of new, or contemporary, cosmopolitan contexts, especially the current crisis precipitated by Donald Trump's proposed changes to U.S. immigration policy. Sosnowska counterbalances her general framing of cosmopolitanism with a focus on a particular diasporic enclave through a reading of Czesław Karkowski's novel, Kamienna drabina (A Stone Ladder, 2007) as well as through interviews she conducted with diasporic Poles towards her doctoral thesis.

\section{Section V: The Powers And Perils Of Cultural Expression}

The new cosmopolitanism seeks to remind of the power of cultural expression to redress or even repair the damage done to both national communities and to the global or planetary ecumene by eruptions of racially motivated violence, by the proliferation of ethnic splinterings, cross-border war between ethnonationalist groups, internecine conflicts within multiethnic nation-states, or simply by the depredations of a global capitalism too often unipolar and tilted in favor of Western economies. Against the ravages of an ever-advancing globalization of culture and economy, the new cosmopolitanism seeks to foster possibilities for global, or transnational, solidarity. It also seeks to nurture space for resistance to both universalist binaries of the global North versus the Global South and ethnocentric or parochial normativity-cosmopolitics from below. Several chapters in this volume highlight forms of minoritarian agency in narratives that foreground resistance to mainstream conceptualizations of citizenship and normative modes of citizenship and subjectivity. They also highlight what might be called the creative and "re-creative" potential of new cosmopolitanismscreative practices including hybrid music and creolized languages-to negotiate new identity positions that refuse circumscription within territorial nation-space borders. 
Annarita Taronna focuses on the powers of cultural expression in her chapter "Black English and the New Cosmopolitanism: Karima 2G's Linguistic Creativity as a Transethnic Performative Practice.” She takes as her primary text the linguistic performance of the African-Italian Anna Maria Gehnyei ("Karima 2G"), a second-generation Liberian immigrant to Italy, whose "new cosmopolitan" rap performance and narration index the "linguistic and cultural history of the color line in Italy." Karima $2 \mathrm{G}$ 's rap refracts a pidgin English to both represent and complicate the racialized marginalization of Black diasporic "geo-localities and linguistic identities" in Italy, and more generally to resist essentialisms of identity that reify categories of "race" and ethnicity. Anti-immigrant sentiment in Italy is as much her subject as her own Liberian background, which becomes the source of yet another expression of the postcolonialist "rooted cosmopolitanism" that is a connecting thread among many chapters in this volume. In her "ethno-socio-linguistic analysis," Taronna explores, in a pluriversalist idiom, the transnational linkages cutting across national cultural music and "plurilithic Englishes" across the African and European contexts, not to mention an at least imagined routing to the U.S. experience of slavery and its aftermath.

The ethicopolitical obligation of the host within a new framing of cosmopolitan right in the contemporary conjuncture is a ticklish subject, and carries with it certain risks. For one thing, even well-meaning official protocols instituted to assess claims of such rights can pose ethical and other-even pragmatic or procedural-quandaries. Tingting Hui in her chapter proposes "to examine the perils of public policy embedded in the idea of cosmopolitan hospitality from the aspects of language and speech." Yet it is not so much discourse that interests Hui but rather "accent." She focuses on "the law that urges the other to speak like the other and to demonstrate an 'authentic' accent that testifies to one's singular mother tongue.” Hui considers language analysis-the "accent test," used internationally since the 1990s in asylum procedures to verify and determine the countries of origin of applicants." In evaluating the debate about the accent test as forensic evidence, as "a modern version of the 'shibboleth test,' " Hui considers Lawrence Abu Hamdan's audio documentary work The Freedom of Speech Itself (2012) as a primary illustration of the way a split is introduced between the "voicing of language and the voicing of body." The "evidence" of accent may introduce complications into the process of authentication of identity, especially by border agencies dealing with asylum seekers. Hui thus invokes Derrida's suggestion that "the language of total intimacy is to be found only in profound silence" to elaborate a larger argument about the ethics of listening. By the same token she also highlights the ethics of hearing the accent in the case of ideologically charged contexts such as those an asylum seeker might encounter at the border.

Declaring that he is a "keeper of lists" against infinity, Santiago Vaquera-Vásquez offers an offbeat, audiophile approach to cosmopolitanism: an internationalist "mixtape of my life." As he describes it in his chapter, "Imagining Something Better: Rolas from my Border Hi-Fi," his musical avocation functions almost as a passport 
for border crossing and musicological flâneurie. Such border crossing, the author claims-invoking the work of José David Saldivar-is subversive cosmopolitanism. For it opens an access to identity from "below" that may on occasion "punk" the category itself, in an anti-elitist ("rasquachismo") gesture simultaneously of refusal and selfaffirmation. A minoritarian cosmopolitanism fractures-from the margins-the monumentalism of the hierarchized global structuration of the Global North versus the Global South. This episodic travelogue the author intends ("hears" or wants heard) as a (post-)Chicano's cosmopolitical autobiography that interrogates the meaning of cultural identity and citizenship in the United States rather than seeking assimilation into a mainstreamed cosmopolitanism.

To open her nuanced meditation on albinism and its complication of identity in Barbara Chase-Riboud's 1979 novel, Sally Hemings, Sheena Garrant explores the via negativa through which the sculptor and poet approaches the social constructions of the categories of race and ethnicity. She foregrounds the figure of the albino, a special kind of hybrid (here represented by Hemings, the slave who was also mother to Thomas Jefferson's children). The albino is the "walking negative" who makes race radically undecidable. Chase-Riboud confronts the reader/spectator directly, so that this rendering undecidable is not treated as yet another academic or intellectual conceit. All of the artist/novelist's work is structured as an intervention in public (political and even cosmopolitical) discourse. Her sculptural mediation in The Albino inverts a presumptively normative whiteness, rendering it an effect of lackmost immediately and obviously a deficit of melanin-rather than self-sufficient and autotelic presence. In discussing the novel, Chase-Riboud analogously relativizes the constructs of race and ethnicity. The eponymous "heroine" is at once white (as on the novel's cover) and black, depending on the perspective of the observer (or character in the novel). But ideologically too her work subverts the normativity and iconicity of whiteness as fullness of being. Her epistemological interruption-relativization, hybridization-posits an irreducible ontological difference, or through the logic of différance, interminable deferral. "The color problem" now is displaced onto the other side of the machinery of "othering," to foreground the aesthetics and ethics of creolization. Taken together, and speaking to one another, the essays in this book thus add a new and unpredictable set of approaches towards thinking in a more capacious way about a new cosmopolitics to come.

\section{Works Cited}

Appiah, Kwame Anthony. "Rooted Cosmopolitanism." The Ethics of Identity. Princeton UP, 2005, pp. 213-272. 
Beck, Ulrich. Risk Society: Towards a New Modernity. 1986. Translated by Mark Ritter, Sage, 2005. Benítez-Rojo, Antonio. The Repeating Island: The Caribbean and the Postmodern Perspective. 2nd ed., translated by James Maraniss, Duke UP, 1996.

Breckenridge, Carol, et al. Cosmopolitanism. Duke UP, 2002.

Casarino, Cesare. "Universalism of the Common." diacritics, vol. 39, no. 4, Winter 2009, pp. 162-176.

Davidson, Donald. "On the Very Idea of a Conceptual Scheme." Proceedings and Addresses of the American Philosophical Association, vol. 47, 1973-1974, pp. 5-20.

Dayal, Samir. "Diaspora and Double Consciousness." The Journal of the Midwest Modern Language Association, vol. 29, no. 1, Spring 1996, pp. 46-62.

Forte, Maximilian, editor. Indigenous Cosmopolitans: Transnational and Transcultural Indigeneity in the Twenty-First Century. Peter Lang, 2010.

Gilroy, Paul. After Empire: Melancholia or Convivial Culture? Routledge, 2004.

Grewal, Inderpal. Transnational America: Feminisms, Diasporas, Neoliberalisms. Duke UP, 2005.

Kant, Immanuel. "Perpetual Peace." International Relations and Political Theory, edited by Howard Williams et al., UBC P, 1993, pp. 113-121.

--.. "Toward Perpetual Peace: A Philosophical Sketch." 1795. Toward Perpetual Peace and Other Writings on Politics, Peace, and History (Rethinking the Western Tradition, edited by Pauline Kleingeld, translated by David L. Colclasure, Yale UP, 2006, pp. 67-109.

--.. "The Metaphysics of Morals." Kant's Political Writings. 2nd ed., edited by Hans Reiss, Cambridge UP, 1991, pp. 131-175.

Koshy, Susan. “Minority Cosmopolitanism." PMLA, vol. 126, no. 3, May 2011, pp. 592-609.

Latour, Bruno. An Inquiry into Modes of Existence: An Anthropology of the Moderns. Harvard UP, 2013.

---. We Have Never Been Modern. 1991. Harvard UP, 1993.

--.. "Whose Cosmos, Which Cosmopolitics? Comments on the Peace Terms of Ulrich Beck." Common Knowledge, vol. 10, no. 3, 2004, pp. 450-462.

Nixon, Rob. Slow Violence and the Environmentalism of the Poor. Harvard UP, 2013.

Pollock, Sheldon, et al. "Cosmopolitanisms." Public Culture, vol. 12, no. 3, pp. 577-589.

Sassen, Saskia. The Global City: New York, London, Tokyo. Princeton UP, 2013.

Stengers, Isabelle. Cosmopolitics II. Translated by Robert Bononno, U of Minnesota P, 2011.

--.. "The Cosmopolitical Proposal." Making Things Public: Atmospheres of Democracy, edited by Bruno Latour and Peter Weibel, MIT P, 2005, pp. 994-1003.

The United Nations. Universal Declaration of Human Rights. 1948.

Tölölyan, Khachig. "Rethinking Diaspora(s): Stateless Power in the Transnational Moment." Diaspora: A Journal of Transnational Studies, vol. 5, no. 1, Spring 1996, pp. 3-36.

Torpey, John. The Invention of the Passport: Surveillance, Citizenship and the State. Cambridge UP, 1999.

Trethewey, Natasha. Beyond Katrina: A Meditation on the Mississippi Gulf Coast. U of Georgia P, 2010.

--.. Thrall: Poems. Houghton Mifflin Harcourt, 2012.

Vertovec, Steven, and Robin Cohen. Introduction. Conceiving Cosmopolitanism: Theory, Context and Practice. Oxford UP, 2002, pp. 1-22. 